\title{
Changes in hospital management of acute severe asthma by thoracic and general physicians in Birmingham and Manchester during 1978 and 1985
}

\author{
D R Baldwin, L P Ormerod, A D Mackay, D E Stableforth
}

Department of Thoracic Medicine, Dudley Road Hospital, Birmingham

D R Baldwin

Blackburn Royal

Infirmary,

Blackburn

L P Ormerod

Department of

Thoracic Medicine,

Sandwell District

General Hospital,

Lyndon,

West Bromwich

A D Mackay

East Birmingham

Hospital,

Birmingham

D E Stableforth

Address for reprint requests:

Dr D R Baldwin,
Dudley Road Hospital

Dudley Road Hospital,
Birmingham B18 7QH

Accepted 19 October 1989

\begin{abstract}
Hospital management of acute severe asthma in 14 large hospitals in Birmingham and Manchester was audited in a random $20 \%$ of 1196 patients aged $15-45$ years admitted in 1985 . Of the 239 admissions randomised, 192 were suitable for study. Results were compared with those from a study in the same hospitals using the same methods in 1978. The age and sex of the patients and their smoking history, duration of asthma, and hospital attendance were similar in 1978 and 1985. A much smaller proportion of patients presented with symptoms of over seven days' duration in $1985(8 \cdot 5 \%)$ than in 1978 $(26 \%)$. The inpatient management of asthma appears to have improved in both thoracic and general units, with more thorough functional assessments, more frequent performance of relevant investigations (arterial blood gases and peak expiratory flow rates) and more frequent use of recommended treatment (nebulised bronchodilators, oral and intravenous corticosteroids). Less difference was found in 1985 between units with a specialist thoracic interest and those without, though some differences remained in 1985 in monitoring of peak expiratory flow rate and arterial blood gases, outpatient prescribing, and follow up arrangements. Inhaled preventive medication was prescribed more frequently than in 1978. In 1985 there was a $56 \%$ increase in admissions for asthma. The proportion of severely ill patients was similar to that in 1978 , but in the most severe functional grade mean arterial carbon dioxide tension was higher in 1985 and more patients were ventilated. Our results suggest that hospital management by thoracic and general physicians has improved over the period 1978-85. Patients presented earlier in 1985, though there seems to have been an increase in asthma of all grades of severity.
\end{abstract}

Asthma morbidity, mortality, and prevalence are reported to be rising in the United Kingdom ${ }^{12}$ and New Zealand, ${ }^{34}$ though there is controversy about whether this rise is real or an artefact due to difficulties in determining these indices in epidemiological studies of asthma. ${ }^{25}$ Despite improved hospital man- agement, ${ }^{5}$ treatment that appears to be more effective, and increased drug prescribing ${ }^{56}$ there have been no reports of a decline in prevalence. Reasons for this paradox could be deficiencies in the management of asthma, increased prevalence or severity, a change in diagnostic fashion, or a combination of these factors. To investigate the first possibility, studies have compared hospital management by specialist thoracic physicians with nonspecialist general physicians. ${ }^{8-11}$ Others have looked for a change in the severity of asthma by studying prescribing practices, ${ }^{6}$ general practice consultations, ${ }^{5}$ admission and discharge rates, ${ }^{7}$ and results of bronchial challenge tests $^{1213}$ but no firm conclusions have been reached.

We have studied the management of patients with acute asthma admitted in 1985 to 14 major hospitals in Birmingham and Manchester and compared the findings with those obtained in a similar study in 1978 in the same 14 hospitals. ${ }^{8}$

\section{Methods}

The same method was used to examine the case notes for 1985 as was used in $1978 .^{8}$ Patients aged 15-45 years admitted with a diagnosis of acute asthma were identified from Hospital Activity Analysis statistics. The same 14 major hospitals in Birmingham and Manchester were studied with the approval of the local ethical committees. A random $20 \%$ of acute admissions from each hospital were surveyed to obtain a manageable number. Written permission to examine patients' records was sought from individual consultants. Patients were excluded when permission was refused.

Hospital case notes and nursing observations were examined, and when there was sufficient detail the severity of asthma was graded, as in 1978 , on the following functional scale adapted from Jones ${ }^{14}$ :

Grade 1-patient able to carry out job or housework with difficulty; sleep disturbed by asthma, but able to sleep; no relief from inhaler.

Grade $2 A$-patient confined to chair or bed, but able to rise with moderate difficulty to perform actions such as making a cup of tea.

Grade $2 B$-patient confined to chair or bed but able to rise with great difficulty; unable to sleep.

Grade 3-patient totally confined to the chair or bed.

Grade 4-patient completely exhausted.

Pulse rate was not used to determine functional category. Aspects of management by specialist 
Table 1 Clinical characteristics of patients studied

\begin{tabular}{|c|c|c|c|}
\hline Patients' characteristics & $\begin{array}{l}1978 \\
(n=140)\end{array}$ & $\begin{array}{l}1985 \\
(n=192)\end{array}$ & $\begin{array}{l}95 \% \text { confidence } \\
\text { limits } \dagger \text { of difference }(\%)\end{array}$ \\
\hline \multirow{5}{*}{$\begin{array}{l}\text { Age (y): mean } \\
\text { range } \\
\text { Males }\left({ }^{\circ}{ }_{0}\right) \\
\text { Smokers }\left({ }^{\circ}{ }_{0}\right) \\
\text { Duration of attack before } \\
\text { admission }\left(\text { No }\left({ }^{\circ}{ }_{0}\right)\right) \\
\leqslant 24 \text { hours } \\
\text { 2-7 days } \\
8-28 \text { days } \\
>28 \text { days }\end{array}$} & $\begin{array}{l}28 \\
15-45\end{array}$ & $\begin{array}{l}28 \\
15-45\end{array}$ & \\
\hline & & & $-0.8,20 \cdot 8$ (NS) \\
\hline & & & $-6.9,12.6(\mathrm{NS})$ \\
\hline & $\mathrm{n}=139$ & $\mathrm{n}=169$ & \\
\hline & $\begin{array}{c}54(39) \\
48(34) \\
34(24) \\
3(2)\end{array}$ & $\begin{array}{c}63(37) \\
93(55) \\
12(7) \\
1(0.5)\end{array}$ & $\begin{array}{l}\text { NS } \\
9 \cdot 3,31 \cdot 7^{\star \star \star} \\
9 \cdot 4,25 \cdot 4^{\star \star \star} \\
\text { NS }\end{array}$ \\
\hline
\end{tabular}

†Based on the difference in proportions.

$\star \star \star \mathrm{p}<0.001 ; \mathrm{NS}-\mathrm{p}>0.05$.

Table 2 Hospital attendance for asthma *

\begin{tabular}{|c|c|c|}
\hline & $\begin{array}{l}1978 \\
(n=140) \\
\text { No }(\%)\end{array}$ & $\begin{array}{l}1985 \\
(n=192) \\
\text { No }(\%)\end{array}$ \\
\hline $\begin{array}{l}\text { Current outpatient supervision } \\
\text { Previous admission with acute severe asthma } \\
\text { Admission with asthma in preceding } 28 \text { days }\end{array}$ & $\begin{array}{l}51(36) \\
79(56) \\
14(10)\end{array}$ & $\begin{array}{l}67(35) \\
107(56) \\
12(6)\end{array}$ \\
\hline $\begin{array}{l}\text { Casualty attendance for asthma at accident and } \\
\text { emergency department within seven days }\end{array}$ & $7(5)$ & $3(1 \cdot 5)$ \\
\hline
\end{tabular}

^All differences are non-significant $(p>0.05)$.

thoracic physicians were compared with management by general physicians not claiming a special interest in thoracic medicine. Results were analysed by using the $\chi^{2}$ test with Yates's correction and Fisher's exact probability test and by calculating standard errors of the differences in proportions to derive $95 \%$ confidence intervals.

\section{Results}

In 19851196 patients aged 15-45 years were admitted from the two catchment areas. This represents a $56 \%$ increase on the 766 admissions in 1978. Total deaths and discharges in the same age group had increased by $8.5 \%$ in 1985 (1978: 100 426; 1985: 108 957). Asthma admissions to each hospital were also classed by residence code and showed no change between the two years. Two patients died in 1985.

Of the 1196 admissions, $239(20 \%)$ were randomly selected for study, but in 47 cases either the records were untraceable $(20$, including one death) or they had insufficient evidence of acute asthma (12) or permission to

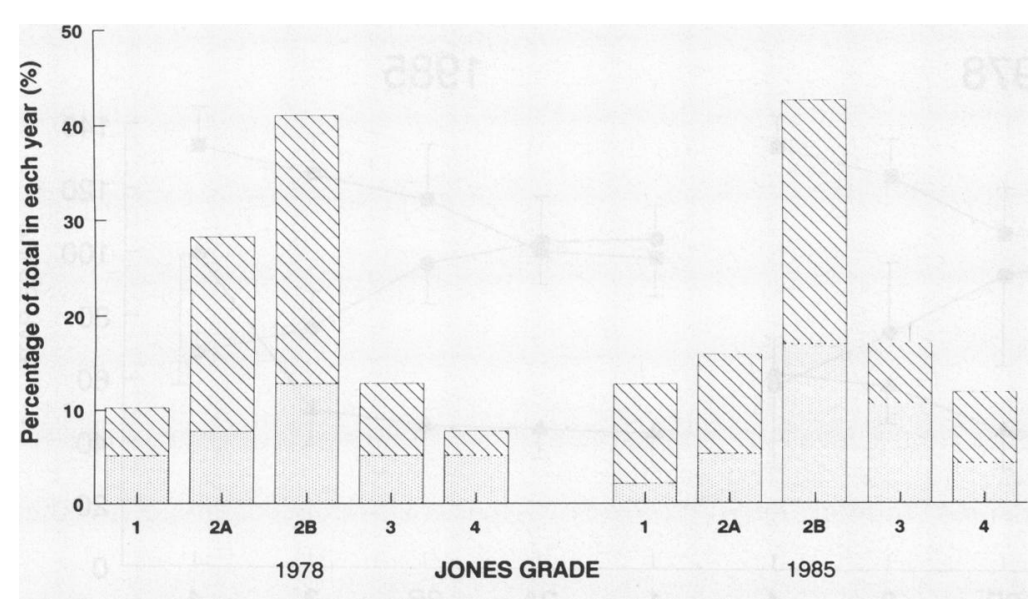

Figure 1 Distribution of patients under general physicians (國) and under thoracic

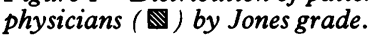

view the notes was refused (16). Thus 192 case notes remained for analysis.

The characteristics of the patients studied are shown in table 1 with the information for 1978 for comparison. There was a highly significant difference for the duration of the presenting attack, $24 \%$ of patients presenting with a relatively long attack of eight to 28 days in 1978 compared with only $7 \%$ in 1985, whereas more patients had a shorter attack of two to seven days in 1985 (55\% in $1985,34 \%$ in 1978).

There were no differences in previous admission rates, recent admission, or outpatient follow up for asthma between 1978 and 1985 (table 2). A similar proportion of patients were admitted to units with a thoracic interest in $1978(48 \%)$ and $1985(49 \%)$.

\section{INITIAL ASSESSMENT}

Sufficiently detailed case notes made it possible to grade $85 \%$ of partients on a functional scale in 1985 compared with only $55 \%$ in 1978 . Figure 1 shows the distribution of functional severity, in the patients' in whom this could be assessed, in general and thoracic units in 1978 and 1985. The proportion in each functional grade in 1978 and 1985 did not differ significantly.

Objective measures of severity of asthma (peak expiratory flow and arterial blood gases) were recorded more frequently by thoracic physicians than by general physicians in both 1978 and 1985 (table 3). These measures were also recorded more frequently in 1985 than in 1978 (table 3). Figure 2 shows the relation between the functional grade recorded on admission with pulse rate, arterial carbon dioxide tension $\left(\mathrm{PaCO}_{2}\right)$, and arterial oxygen tension $\left(\mathrm{PaO}_{2}\right)$ in 1978 and 1985. These measures of severity were broadly similar between the two years, though $\mathrm{PaO}_{2}$ was higher in group 4 in $1985 . \mathrm{PaO}_{2}$ was often recorded while the patient was receiving supplementary oxygen.

\section{INITIAL AND MAINTENANCE TREATMENT}

In 1978 non-thoracic units were more likely to give a bolus of intravenous aminophylline than thoracic units $(77 \% \quad v 44 \%)$. In 1985 the difference was not significant $(24 \% \quad v \quad 17 \%)$. The proportion of patients receiving a bolus injection of aminophylline was smaller in 1985 $(20 \%)$ than in $1978(61 \% ; p<0.001)$. Table 4 shows the treatment given in 1978 and 1985.

In 1985 aminophylline was prescribed less, whether as a single bolus or an infusion or combined with inhaled bronchodilators. Metered dose inhalers were used less as initial treatment and nebulisers were used almost universally. Oral prednisolone was given more often in 1985 and intravenous hydrocortisone was more likely to be continued beyond a single dose.

In 1985 the initial treatment given by thoracic and general units did not differ significantly except that thoracic units were more likely to give infused hydrocortisone (95\% confidence limits $1 \cdot 4,29 \cdot 1$ ).

Nine patients in the $20 \%$ sample (five from 
Table 3 Recording of information at initial assessment (a) Thoracic versus general physicians

\begin{tabular}{|c|c|c|c|}
\hline & $\begin{array}{l}\text { Thoracic } \\
\text { No }(\%)\end{array}$ & $\begin{array}{l}\text { General } \\
\text { No }(\%)\end{array}$ & $\begin{array}{l}95 \% \text { confidence } \\
\text { limits of difference (\%) }\end{array}$ \\
\hline $\begin{array}{l}1978 \\
\text { History of functional }\end{array}$ & $\mathrm{n}=67$ & $\mathrm{n}=73$ & \\
\hline $\begin{array}{l}\text { impairment } \\
\text { Peak flow or spirometry } \\
\text { Arterial blood gases }\end{array}$ & $\begin{array}{l}44(66) \\
37(55) \\
39(58)\end{array}$ & $\begin{array}{c}33(45) \\
6(8) \\
20(27)\end{array}$ & $\begin{array}{l}4 \cdot 0,37 \cdot 0^{\star} \\
31 \cdot 7,62 \cdot 3^{\star \star \star} \\
14 \cdot 6,47 \cdot 4^{\star \star \star}\end{array}$ \\
\hline $\begin{array}{l}1985 \\
\text { History of functional }\end{array}$ & $\mathrm{n}=94$ & $\mathrm{n}=98$ & \\
\hline $\begin{array}{l}\text { impairment } \\
\text { Peak flow or spirometry } \\
\text { Arterial blood gases }\end{array}$ & $\begin{array}{l}82(87) \\
76(81) \\
64(68)\end{array}$ & $\begin{array}{l}81(83) \\
54(55) \\
43(44)\end{array}$ & $\begin{array}{l}\text { NS } \\
12 \cdot 8,39 \cdot 1^{\star \star \star} \\
10 \cdot 2,38 \cdot 3^{\star \star}\end{array}$ \\
\hline
\end{tabular}

(b) 1978 versus 1985

\begin{tabular}{|c|c|c|c|}
\hline & $\begin{array}{l}1978 \\
\text { No }(\%)\end{array}$ & $\begin{array}{l}1985 \\
\text { No }(\%)\end{array}$ & $\begin{array}{l}95 \% \text { confidence } \\
\text { limits of difference (\%) }\end{array}$ \\
\hline $\begin{array}{l}\text { Thoracic ward } \\
\text { History of functional }\end{array}$ & $\mathrm{n}=67$ & $\mathrm{n}=94$ & \\
\hline $\begin{array}{l}\text { impairment } \\
\text { Peak flow or spirometry } \\
\text { Arterial blood gases }\end{array}$ & $\begin{array}{l}44(66) \\
37(55) \\
39(58)\end{array}$ & $\begin{array}{l}82(87) \\
76(81) \\
64(68)\end{array}$ & $\begin{array}{l}8 \cdot 1,33 \cdot 9 \star \star \\
11 \cdot 7,40 \cdot 3 \star \star \star \\
-5 \cdot 0,25 \cdot 0 \mathrm{NS}\end{array}$ \\
\hline General ward & $\mathrm{n}=73$ & $\mathrm{n}=98$ & \\
\hline $\begin{array}{l}\text { impairment } \\
\text { Peak flow or spirometry } \\
\text { Arterial blood gases }\end{array}$ & $\begin{array}{c}33(45) \\
6(8) \\
20(27)\end{array}$ & $\begin{array}{l}81(83) \\
54(55) \\
43(44)\end{array}$ & $\begin{array}{l}23 \cdot 8,52 \cdot 2^{\star \star \star} \\
32 \cdot 5,61 \cdot 5^{\star \star \star} \\
2 \cdot 2 \cdot 31 \cdot 8^{\star}\end{array}$ \\
\hline
\end{tabular}

${ }^{\star} \mathrm{p}<0.05 ;{ }^{\star \star} \mathrm{p}<0.01 ;{ }^{\star \star \star} \mathrm{p}<0.001$

$\mathrm{NS}-\mathrm{p} \geqslant 0.05$

Table 4 Initial treatment in 1978 and 1985 (figures combined for thoracic and general physicians)

\begin{tabular}{|c|c|c|c|}
\hline & $\begin{array}{l}1978(n=140) \\
\text { No }(\%)\end{array}$ & $\begin{array}{l}1985(n=192) \\
\text { No }(\%)\end{array}$ & $\begin{array}{l}95 \% \text { confidence } \\
\text { limits of difference }(\%)\end{array}$ \\
\hline $\begin{array}{l}\text { Intravenous bronchodilator } \\
\text { Bolus (aminophylline) } \\
\text { Infusion (aminophylline) } \\
\text { None }\end{array}$ & $\begin{array}{l}85(61) \\
67(48) \\
41(29)\end{array}$ & $\begin{array}{r}39(20) \\
58(30) \\
126(66)\end{array}$ & $\begin{array}{l}30 \cdot 5,51 \cdot 5^{\star \star} \\
7 \cdot 0,28 \cdot 1^{\star} \\
25 \cdot 5.47 \cdot 5^{\star \star}\end{array}$ \\
\hline $\begin{array}{l}\text { Inhaled bronchodilator } \\
\text { Metered dose } \\
\text { Nebuliser } \\
\text { Neither }\end{array}$ & $\begin{array}{l}54(39) \\
45(32) \\
42(30)\end{array}$ & $\begin{array}{c}3(2) \\
189(79) \\
0\end{array}$ & $\begin{array}{l}\star \star \dagger \\
\star \star \dagger \\
\star \star \dagger\end{array}$ \\
\hline $\begin{array}{l}\text { Corticosteroids } \\
\text { Intravenous } \\
\text { Oral } \\
\text { None except one bolus }\end{array}$ & $\begin{array}{l}62(44) \\
83(59) \\
52(37)\end{array}$ & $\begin{array}{r}77(40) \\
152(79) \\
34(18)\end{array}$ & $\begin{array}{l}-6 \cdot 6,14 \cdot 9 \mathrm{NS} \\
10 \cdot 0,29 \cdot 8^{\star \star} \\
9 \cdot 9,28 \cdot 9^{\star \star}\end{array}$ \\
\hline
\end{tabular}

${ }^{\star} p<0.01 ;{ }^{\star \star} p<0.001 ;$ NS- $p \geqslant 0.05$

$\dagger$ Fisher's exact test.

Figure 2 Correlation of functional grade with mean arterial oxygen tension (-), carbon dioxide tension $(-t)$, and pulse rate $(-5)$

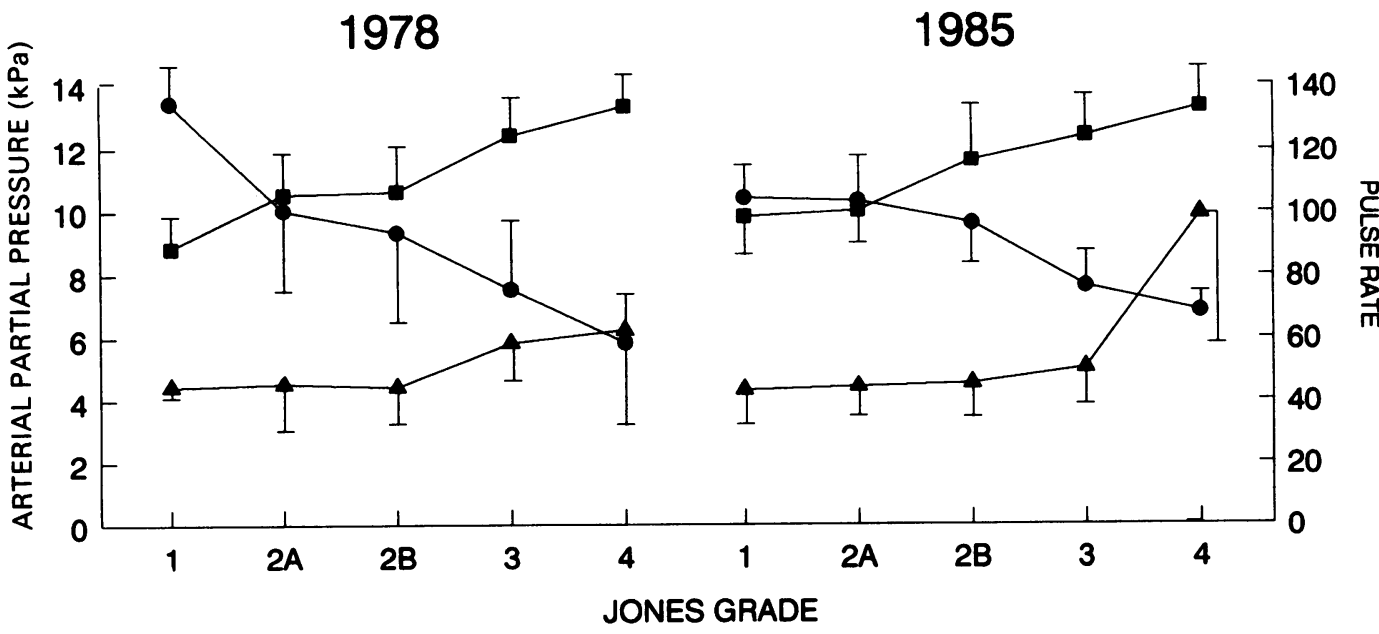

thoracic units) required assisted ventilation in 1985 whereas no patients were ventilated in 1978 ( $p=0.013$ ). Eleven patients were classified as Jones grade 4 in 1985 compared with four in 1978, and the mean $\mathrm{PaCO}_{2}$ of these patients was higher $(9.9 v 6.5 \mathrm{kPa} ; \mathrm{p}=0.02$, Student's $t$ test).

The median duration of hospital stay was 6 (range 1-21) days for patients in thoracic wards and 4.5 (range 1-28) days for patients in general wards. These figures compare with 8 (range 2-36) days and 5 (range 1-22) days in 1978.

Discharge treatment and follow up is shown in table 5. As in 1978, thoracic units were still more likely to prescribe oral corticosteroids and to arrange outpatient follow up. In 1985, however, there was no significant difference in the number of patients prescribed inhaled preventive drugs by general wards and by thoracic units, though inhaled and oral corticosteroids were prescribed more frequently by both groups in 1985 than in 1978 (table 5).

\section{Discussion}

The apparent rise in morbidity and mortality from asthma has led to concern about the quality of management of the disease both in the community and in hospital. Studies comparing hospital management by specialist thoracic physicians and by general physicians and physicians with other specialist interests ${ }^{8-11}$ have concluded that there are deficiencies in hospital management of acute severe asthma that are worse in general units. ${ }^{8-11}$ These studies have looked at management at a particular point in time and provide no information about change in hospital management. Our study has enabled us to compare the characteristics of patients admitted to hospital with acute asthma in 1978 and 1985 and clinical management by specialist and non-specialist physicians during the same years.

In both years about half the patients were treated by a thoracic specialist. Thus half of all acute severe asthma in the two regions is managed by a general physician without a thoracic interest. Clearly therefore pleas for optimum management need to be addressed equally to general and thoracic colleagues.

In the two years the patients were similar in 
Table 5 Discharge treatment and follow up

\begin{tabular}{|c|c|c|c|c|c|c|c|c|c|}
\hline & \multicolumn{6}{|c|}{ General and thoracic units, 1978 and 1985} & \multicolumn{3}{|c|}{ Combined patients for 1978 and 1985} \\
\hline & \multicolumn{3}{|l|}{1978} & \multicolumn{3}{|l|}{1985} & \multirow{2}{*}{$\begin{array}{l}\frac{1978}{\text { Total }} \\
(n=140) \\
\%\end{array}$} & \multicolumn{2}{|l|}{1985} \\
\hline & $\begin{array}{l}\text { Thoracic } \\
(n=67) \\
\%\end{array}$ & $\begin{array}{l}\text { General } \\
(n=73) \\
\%\end{array}$ & $\begin{array}{l}95 \% \text { confidence } \\
\text { limits of } \\
\text { difference }(\%)\end{array}$ & $\begin{array}{l}\text { Thoracic } \\
(n=67) \\
\%\end{array}$ & $\begin{array}{l}\text { General } \\
(n=73) \\
\%\end{array}$ & $\begin{array}{l}95 \% \text { confidence } \\
\text { limits of } \\
\text { difference }(\%)\end{array}$ & & $\begin{array}{l}\text { Total } \\
(n=192) \\
\%\end{array}$ & $\begin{array}{l}95 \% \text { confidence } \\
\text { limits of } \\
\text { difference }(\%)\end{array}$ \\
\hline $\begin{array}{l}\text { Discharged on oral steroids } \\
\text { Discharged on inhaled }\end{array}$ & 54 & 33 & $4 \cdot 4,37 \cdot 3^{\star}$ & 86 & 61 & $12 \cdot 5,37 \cdot 5 \star \star \star$ & 43 & 73 & $19 \cdot 9,41 \cdot 2^{\star \star}$ \\
\hline $\begin{array}{l}\text { preventive drugs } \\
\text { Outpatient follow up arranged }\end{array}$ & $\begin{array}{l}46 \\
95\end{array}$ & $\begin{array}{l}19 \\
68\end{array}$ & $\begin{array}{l}11 \cdot 6,42 \cdot 6^{\star \star \star} \\
12 \cdot 5,41 \cdot 5^{\star \star \star}\end{array}$ & $\begin{array}{l}85 \\
94\end{array}$ & $\begin{array}{l}74 \\
74\end{array}$ & $\begin{array}{l}-0 \cdot 8,22 \cdot 0 \mathrm{NS} \\
8 \cdot 7,29 \cdot 5^{\star \star}\end{array}$ & $\begin{array}{l}32 \\
81\end{array}$ & $\begin{array}{l}80 \\
84\end{array}$ & $\begin{array}{l}36 \cdot 9,58 \cdot 3^{\star \star} \\
-5 \cdot 8,10 \cdot 6 \mathrm{NS}\end{array}$ \\
\hline
\end{tabular}

${ }^{\star} \mathrm{p}<0.05 ;{ }^{\star \star} \mathrm{p}<0.01 ;{ }^{\star \star \star} \mathrm{p}<0.001 ; \mathrm{NS}-\mathrm{p} \geqslant 0.05$.

terms of age, sex, smoking, duration of asthma, and hospital attendance. The similar relation between functional grade and pulse rate, $\mathrm{PaCO}_{2}$, and $\mathrm{PaO}_{2}$ suggests that the grades assigned to patients from the two periods are comparable.

The $56 \%$ increase in asthma admissions (compared with an $8.5 \%$ increase in total admissions) and the increase in numbers of ventilated patients with less favourable blood gas tensions suggests an increase in prevalence of asthma and more severe asthma in those admitted to hospital in 1985. This is at first sight contradicted by the similar proportion of patients in the different functional grades (fig 1). There are two points, however, that might explain the similar proportion despite the larger number of ventilated patients in 1985 . Firstly, patients tended to present earlier in 1985, which would be expected to reduce their grade of severity on admission and boost the numbers of patients in the less severe functional grades. Secondly, it was generally easier for observers to grade patients with the more severe asthma. The relatively low number of patients who could be graded in 1978 might conceal a large number of less severely affected patients.

Possibly acute asthma was diagnosed more readily in 1985, leading to an increase in numbers. We think this is improbable, as a change in diagnostic category is unlikely to make such a large difference in the 15-45 year age range.

The initial assessment of patients showed some improvement between the two periods. The keeping of better case notes meant that more patients could be graded in 1985 . There was evidence of a more complete examination, including the more frequent measurement of arterial paradox; and relevant investigations (arterial blood gas tensions and peak expiratory flow) were performed more frequently in 1985. A difference between thoracic and nonthoracic physicians was still present in 1985, though it was less than in 1978 (table 3), reflecting better recording of initial assessment in thoracic units.

The use of nebulised bronchodilators increased greatly between 1978 and 1985 and they have clearly become standard first line treatment. The use of intravenous aminophylline and other intravenous bronchodilators fell, presumably because of increased awareness of theophylline toxicity plus the knowledge that they are no more efficacious than beta ${ }_{2}$ agonist bronchodilators. ${ }^{1516}$ Oral prednisolone is accepted as essential for an established asthma attack. More patients were prescribed this in 1985 in both thoracic and general units.

In 1978 there were many differences in the initial treatment prescribed by general and thoracic physicians but by 1985 these had almost disappeared, suggesting a more uniform approach to the treatment of acute severe asthma. Overall, management appears to have improved for both thoracic and general physicians.

Morbidity from asthma after discharge is known to be lower in patients managed by thoracic physicians. ${ }^{9}{ }^{10}$ We have no data on the morbidity of the patients after discharge but in 1985 thoracic physicians were more likely to prescribe a course of oral corticosteroids and arrange an outpatient follow up appointment. Both of these might be expected to lead to less morbidity after discharge. The substantial increase in prescription of oral corticosteroids and inhaled preventive medication between 1978 and 1985 suggests an overall improvement in the standard of hospital management.

Despite an apparent improvement in assessment and treatment we observed a significant difference in the number of patients requiring assisted ventilation between the two periods. The arterial blood gases in the most severely affected group suggest that the patients had more severe asthma than in 1978 , not that the physicians' threshold for ventilation was lower (fig 2).

Hospital management of acute severe asthma appears to have improved between 1978 and 1985. The 1978 study is unlikely to have had a specific effect on the particular hospitals concerned because the results of the study were not well publicised. We believe that the changes in management are more likely to be a response to more general recommendations for better management and that the changes seen in these hospitals are representative of most others. In $197836 \%$ of patients under the care of general physicians and $18 \%$ of those under thoracic physicians were not even treated with an inhaled bronchodilator. In 1985 more standardised treatment regimens seem to have been used. Asthmatic patients presented earlier in 1985 in the two catchment areas. This may be because of increased awareness of the dangers of delay or because those with more severe disease are likely to seek help early. Despite this, slightly more of the patients in 1985 were severely ill on admission, both clinically and according to blood gas analysis.

Our findings suggest that acute severe 
asthma occurred more frequently in 1985 than it did in 1978 in the $15-45$ year old age group and that when it occurred there was a tendency to increased severity-despite improved management in both thoracic and general units and despite earlier presentation. Further improvements in management at home and in hospital might help to combat this. ${ }^{9-11}$

We would like to thank the physicians in Birmingham and Manchester for giving permission to study their patients, Dr J Osman for allowing us to use data collected for the year 1978, Miss Rachel Hatton and Miss Nicola Lees for typing the manuscript, and $\mathrm{Mr}$ T Marshall for statistical advice.

1 Burney PGJ. Asthma mortality in England and Wales: evidence for a further increase 1974-84. Lancet 1986; ii:323-6.

2 Flemming DM, Crombie DL. Prevalence of asthma and hay fever in England and Wales. Br Med J 1987;294:279-83.

Mitchell EA Increasing prevalence of asthma in children. $N$ $Z$ Med J 1983;96:463-4

4 Jackson RT, Beaglehole R, Rea HH, Sutherland DC.
Mortality from asthma: a new epidemic in New Zealand. Br Med J 1982;285:771-4.

5 Hay IFC, Higgenbottam TW. Has the management of asthma improved? Lancet 1987;ii:609-11.

6 Keating G, Mitchell EA, Jackson R, Beaglehole R, Rea HH. Trends in the sales of drugs for asthma in New Zealand, Australia, and the United Kingdom 1975-81. Br Med J 1984;289:348-51.

7 Anderson HR, Bailey P, West S. Trends in the care of acute childhood asthma 1970-8: a regional study. $\mathrm{Br} \mathrm{Med} \mathrm{J}$
cheren 1980;281:1191-4.

8 Osman J, Ormerod LP, Stableforth DE. Management of acute asthma: a survey of hospital practice and comparison between thoracic and general physicians in Birmingham and Manchester. BrJ Dis Chest 1987;81:232-42.

9 Bucknall CE, Robertson C, Moran F, Stevenson RD. Differences in hospital asthma management. Lancet 1988;i:748-50.

10 Bucknall CE, Robertson C, Moran F, Stevenson RD. Management of asthma in hospital: a prospective audit. $\mathrm{Br}$ Management of asthma in

11 Arnold AG, Lane DJ, Zapata E. Current therapeutic practice in the management of acute severe asthma. Br J practice in the management
Dis Chest 1983;77:123-35.

12 Sears MR, Jones DT, Silva PA, Simpson A, Williams SM. The prevalence of bronchial reactivity to inhaled methacholine in New Zealand children. Thorax 1986;41:283-9.

13 Britton WJ, et al. Prevalence of bronchial hyperresponsiveness in children. The relationship between asthma and skin reactivity to allergens in two communities. Int $J$ Epidemiol 1986;15:202-9.

14 Davis B, Gett DM, Sherwood Jones E. A service for the adult asthmatic. Thorax 1980;35:111-3.

15 Arbab OA, Wiggins J, Ayres JG, Stableforth DE. The use of parenteral aminophylline in patients taking slow release theophylline preparations: an observation of clinical practice. Br J Dis Chest 1985;79:161-71. 